\title{
North Carolina Library Association Biennial Reports, 2007-2009
}

\section{Roundtable for Ethnic Minority Concerns (REMCO)}

The following individuals were members of the REMCO Executive Board for the 20072009 Biennium:

- Anne Coleman, Chair

- Evelyn Blount, Vice-Chair/Chair Elect

- Jamane Yeager, Immediate Past Chair

- Tamika Barnes McCollough, Secretary/ Treasurer

- Brenda Stephens, Co-Director

- Robin Imperial, Co-Director (Partial Term)

- Alan Bailey, Co-Director (Partial Term)

The 2009-2011 Slate of Officers (election held September/October 2009) is below:

- Evelyn Blount, Chair

- Philip Cherry, III, Vice-Chair/Chair Elect

- Anne Coleman, Immediate Past Chair

- Shamella Cromartie, Secretary/Treasurer

- Tamika Barnes, Co-Director

- Alan Bailey, Co-Director

\section{Highlights of the 2007-2009 Biennium}

In order to conserve money, the meetings of the round table were held via telephone conferencing, using NCLA's ReadyTalk.

Anne Coleman served on the editorial board of North Carolina Libraries, 2007-2009.

Ad-Hoc Committee on Diversity conducted follow-up on the Survey on the Recruiting and Retention of Library Students of Color that was completed in 2006. The survey was sent out to LIS students again in 2009 and the committee plans to compare the 2009 responses to the 2006 responses. The findings will be published in a library journal.

REMCO Newsletter published spring 2008 and mailed to REMCO members. The summer 2009 newsletter was distributed electronically to current members and former members via the REMCO listserv; it was also distributed to a wider audience via the NClA listservs and the BCALA listserv.

REMCO Co-Director Robin Imperial resigned, and Alan Bailey was appointed by the NCLA Executive Board to serve as codirector for the balance of her term. This appointment was necessary because REMCO bylaws did not address the replacement of a co-director between bienniums.

REMCO Brochure was updated September 2009.

Several membership/recruitment projects were initiated during the biennium. Mailings were sent to former REMCO members encouraging them to reactivate their memberships. E-mails were sent to the same constituents, as well as to the NCLA listservs.

Jamane Yeager served as REMCO liaison to the Biennial Conference Planning Committee.

Jamane Yeager updated the REMCO web site and served on the NCLA Web Site Review Committee that just created the new NCLA Web site which debuted in October 2009.

Nominations for the Roadbuilders' awards were solicited August 2009 via the summer REMCO Newsletter. The winners for 2009 were chosen by the REMCO Executive Board in September.

A change was made to REMCO bylaws via an electronic polling of members in September/ October 2009. The change addressed the replacement of all members of the Executive Board if vacancies occur between biennial conferences. The old bylaws only addressed the replacement of the Chair. This memberapproved change will be presented to the NCLA Executive Board at the first Board meeting.
At the 2009 NCLA Biennial Conference, Greenville, NC, REMCO sponsored/cosponsored the following events/activities:

- REMCO Pre-Conference (Black Belt Librarians) - featuring Warren Graham, security expert/author (co-sponsored with the College \& University Section). REMCO secured an NCLA Project Grant to subsidize the pre-conference.

- REMCO Author Luncheon - featuring Nathan Ross Freeman, playwright and screenwriter (funded by a grant from the North Carolina Humanities Council)

- Workshop - "Diversity: Being Able to Serve by Knowing How to Serve Differences" - featuring Robert Canida, II, Director of the UNCP Multicultural \& Minority Affairs Office, and Vivette Jeffries-Logan, Director, Health Circle; Occaneechi Band of the Saponi Nation

- Workshop - "All Abut Census 2010" (co-sponsored with the Government Resources Section)

- REMCO Table in Registration Area

- Raffle of Southern Seasons Gift Basket

At the REMCO luncheon, the 2009 Roadbuilders' Awards were awarded to the following:

- Academic Librarianship-Jamane Yeager

- Public Librarianship-Charles M. Brown

- Special Librarianship-Jamal L. Cromity

- Library Education-Dr. Claudia J. Gollop

The REMCO Roadbuilders' Award recipients were presented at the Second General Session Ogilvie Lecture at the Biennial Conference.

Respectfully submitted

Anne H. Coleman, Chair 
On October 18, 2007, the Community and Junior College Libraries Section of NCLA met during the $57^{\text {th }}$ Biennial Conference in Hickory, NC.

The following officers were elected to serve on the Executive Committee during the next biennium:

- Chair: Janice Pope, Central Carolina CC

- Vice-Chair/Chair Elect: Jennifer Noga, Guilford Technical CC

- Secretary: Deanna Lewis, Cape Fear CC

- Directors-at-Large: Deana Guido, Edgecombe CC, Allen Mosteller, Cleveland CC

The former chair, Debbie Luck, was also a part of the Executive Committee.

\section{Review of Activities of Executive Committee and Section 2008-2009}

Janice Pope, Chair, attended the Executive Board Orientation on January 24, 2008. She also attended Executive Board quarterly meetings in April, July, and October of 2008 and in January, April, and July of 2009. At these meetings she compiled a report and presented to the board the activities of the Executive Committee. These quarterly reports are available on the NCLA/CJCLS Web site.

The Executive Committee established two priorities for the biennium: to offer an educational opportunity for members and others during 2008 and to revise the section bylaws.

At the Executive Board meeting in January 2008, the chair of the College \& University Section, Betty Garrison, asked if the CJCLS would be interested in co-sponsoring a library instruction conference in the fall. The Executive Committee discussed this and decided this would be a good way for us to fulfill one of our priorities. Beginning in March and throughout the summer and early fall, meetings in person and other communications occurred between the CUS and CJCLS committee members for the planning of the conference. Several members of the Executive Committee spent many hours helping to organize the conference. The Library Instruction 2.0 Conference took place on November 17-18,2008, at the Friday Center in Chapel Hill. There were approximately 120 people in attendance and the written and oral evaluations indicated that the conference was well received. The registration fees covered most of the conference expenses. CUS and CJCLS paid the remaining expenses out of their NCLA Fund Accounts. Because of the differences in members and money in the accounts, CUS paid 2/3 and CJCLS 1/3.

In June of 2008, the Executive Committee voted to provide a $\$ 500$ scholarship to a CJCLS member who had been accepted to attend Track One of the Leadership Institute that was to be held in October 2008. After a review of information submitted by the applicants, the scholarship was awarded to Libby Stone of Gaston College.

In July 2008, Deana Guido, Director-atLarge, took a position at a public library. It was determined at that time that the bylaws did not provide for a way to replace anyone during the biennium except the chair. Phil Barton, NCLA President, was able to appoint a replacement for Deana and in January of 2009, Jason Setzer became a part of the CJCLS Executive Committee.

The revision of the bylaws was discussed in e-mails for several months. In April of 2009, the Executive Committee approved a version of the bylaws. This revision was primarily written by Debbie Luck. Several areas of the bylaws needed to be changed. Some of the revisions were made in response to the need to replace one of the committee members during the biennium. Some changes needed to be made to the number of members needed to approve a vote because it was rare that a quorum of members was ever present at any meeting. Any references to voting only by mail were deleted so ballots can be distributed and votes received by e-mail. The bylaws were approved by the CJCLS members through e-mail and by the Executive Board at the meeting in July 2009.

The decision was also made to select a slate of nominees for the CJCLS Executive Committee and have the members vote on this by e-mail before the conference in October 2009. Jennifer Noga, Deanna Lewis, and Jason Setzer agreed to be the nominating committee. In September 2009, nominees were presented to the membership.

The following officers were elected to serve on the Executive Committee for 2010-2011.

- Chair: Jennifer Noga, Guilford Technical $\mathrm{CC}$
- Vice-Chair (Chair-Elect): Penny Sermons, Beaufort County CC

- Secretary-Treasurer: Deanna Lewis, Cape Fear CC

- Directors-at-Large: Allen Mosteller, Cleveland CC; and Jason Setzer, Davidson County CC

- Past Chair: Janice Pope, Central Carolina $\mathrm{CC}$

In April 2009, proposals for programs to be presented at the NCLA Conference in October were solicited from the members. Because of the budget restrictions on community colleges, the presenters were offered $\$ 100$ to subsidize travel expenses up to $\$ 300$ per presentation. The following were the CJCLS sponsored presentations at the conference:

- The Kaleidoscope of Academic Libraries: Marketing our Services to a MultiGenerational Population-Libby Stone and Jody Mosteller, Gaston College Libraries

- Painting with a Broad Brush: Valuing the Competencies of the Community College Library Staff-Michael Crumpton, University of North Carolina Greensboro; and Ellen E. Dickey, Central Carolina Community College

- Mapping Your Trail- Keeping Up With Web 2.0 Developments-Lynn McCormick, Pitt Community College Library

Allen Mosteller has been the coordinator and program contact for the presenters and the NCLA conference planning committee.

Allen has also taken the role of Web editor for the CJCLS section of the NCLA Web site.

The 2008-2009 CJCLS Executive Committee has worked well together and I would like to express my appreciation for all of their hard work.

Respectfully submitted, Janice Pope, Chair 


\section{First Quarter October-January 2009}

At the start of the biennium the committee reviewed the structure and duties of the Membership Committee as outlined in the NCLA Handbook. The committee decided to maintain the NCLA Membership Yahoo Group. Reminders were given to sections and roundtables to designate at least one member to join the yahoo group and to represent their specific section/round table as directed in the NCLA handbook.

The virtual yahoo group was charged with

- Discussing membership development issues and sharing ideas on increasing membership.

- Maintaining a calendar of conferences, regional meetings, and workshops.

- Managing the use of the NCLA membership display for presentations on NCLA.

- Coordinating section and roundtable membership development with the Membership Committee and NCLA as a whole.

- Act as NCLA Ambassadors for membership development at library related events.

The committee started the biennium by researching and working on

- Creating new portable displays for recruitment purposes.

- The revision of membership renewal notices and membership letters.

- The revision of membership applications and brochures.

- Ordering marketing materials to promote NCLA.

- Exploring online payment methods.

During the first quarter membership was promoted at the following events:

- Wake County Libraries Annual Staff Day, Raleigh.

- LAUNC-CH (The Librarians' Association at UNC-CH) Conference, Chapel Hill.

- UNC Teaching and Learning with Technology Conference, Raleigh.

- North Carolina School Library Media Association, Winston-Salem.
The committee requested approval to

- Continue offering special membership pricing at special events for those who join onsite.

- Use the remaining NCLA Conference Store items for giveaways to new members who join onsite or as drawing prizes for NCLA members at events (paid for by project grant funds).

\section{Second Quarter February-April 2008}

The committee worked on the following items:

- Establishing the portable display design/ content.

- Redesigning the membership brochure.

- Promotion at the following workshops:

- Resources and Technical Services Section Spring 2008 Worksho

- What's in a Name? From "Serials" to "Continuing Resources", April 2008, The William and Ida Friday Center for Continuing Education, Chapel Hill

- Exploring alternative marketing ideas.

\section{Third Quarter}

\section{May-July 2008}

The committee worked on the following:

- Held a contest for members to be featured on our portable display signs. The committee reviewed the contest entries. Winners were notified and sent release forms and free memberships were given.

- Joint Membership Proposal for NCPLAThe committee reviewed the NCPLA joint membership proposal from ALA and a motion was prepared for Board.

- Marketing-the committee proposed there be a section on the Web site where section and roundtable members can download applications, brochures, and flyers.

- The committee collaborated with the New Members Round Table on their networking dinners. Membership Committee provided $\$ 5.00$ off applications to anyone who joined at the networking functions. In addition, items were provided for drawings.

- Workshops and conferences:

- Paraprofessional Conference May 16

- RTSS-May 22 Wake Technical College

- Government Resources Section Spring workshop, June 6, 2008

\section{Fourth Quarter August-October 2008}

Since it was an off conference year, there were many fall workshops and conferences held in the fall. The Membership committee worked with several sections and roundtables to have registration materials and displays at the following conferences, workshops, and special events.

- TNT High Tech/ Low Cost Solutions for Libraries Workshop August 4, 2008.

- BLINC-all day workshop with SLA-NC Sept 18, 2008 at the NC Biotech Center.

- Academic Business Collections: a discussion about formats, budgets, content, and weeding, Monday, Sept. 22, $10 \mathrm{am}-3 \mathrm{pm}$, at Jackson Library, UNC Greensboro

- Music in Libraries Workshop at ECU, October 9

- New Members Roundtable Networking Dinners September and October (provided giveaways)

- Youth Services Section Retreat, October 2008 (provided giveaways)

- Reference Services Section, Greensboro Public Library, October 27, 2008.

\section{First Quarter November 2008-January 2009}

The committee worked on the following items:

- The paraprofessional joint application was uploaded to the Web site.Joint membership for students and paraprofessionals was promoted in Tarbeel Libraries and the listserv.

- Brandy Hamilton joined the NCLA Web site Redesign committee to brainstorm and contribute ideas regarding the redesign of the Web site. The main interest of the membership committee was to offer ways to join and pay for membership via the Web site.

- Conferences/workshops:

○ Library Instruction 2.0

- Reviewing the award procedures and advertising nominations for Distinguished Library Service Award, Honorary Membership Award, and the Life Membership Award.

- The budget was submitted to the finance committee for approval. 


\section{Second Quarter}

\section{February-April 2009}

The committee worked on the following items:

- Reviewing the award nominations and submitting a motion for Board approval.

- Following feedback from various members, the Membership Committee reviewed the awards nomination process and decided that award submission forms should be created to provide guidelines for nominees. We also discussed having a more distinct section on the Web site for awards.

- Collaborating with NMRT

- Updating the application and brochure on the Web site and working with the website redesign committee. The Membership Committee brainstormed some ideas and shared them with the Redesign Committee. Ideas included job/career info, joining/renewing capability, 2.0 technologies, and a welcome area that includes a video welcome from the current president.

- Workshops/Conferences/Outreach

- Restructuring the committee to function like a roundtable, including focus areas for committee members such as PR, Outreach, Schools visits, etc.

\section{Third Quarter \\ May-July 2009}

The membership committee worked on the following items:

- Members visited NCCU for their Library Science student orientation on July 17, 2009. The chair and other members spoke about NCLA programs, initiatives, membership opportunities, and the mentoring program. There were around 100 students attending.

- Finalizing the poster for conference.

- Working on the new Web site.

- Notifying NCLA award winners, sending conference invitation letters to recipients. Finalizing the poster for conference.

\section{Fourth Quarter}

\section{August-October 2009}

The committee worked on the following items:

- Biennial conference-The Membership Committee shared a table with NMRT at the conference. Table volunteers spoke to attendees about the benefits of memberships, including networking opportunities, scholarships, the mentoring program, and much more. In addition, a raffle was held. A new membership display banner was also unveiled. Awards were presented on behalf of the committee.
- School visits - committee member Jennie Meyer visited NCCU for their Library Science student orientation in December. She spoke about NCLA programs, initiatives, membership opportunities, and the mentoring program.

- Website progress-Brandy worked with the website redesign committee on editing pages and helping create guidelines for Web administrators. The new Web site went live in January 2009; the membership page was updated, including the new paraprofessional joint NCLA and ALA application.

- New Chair Brandy nominated Jennifer Hanft as membership chair for the next biennium.

- Membership Committee guidelinesBrandy Hamilton will remain on the committee and will soon begin establishing guidelines for operation of the Membership Committee and chair responsibilities.

Respectfully Submitted, Brandy Hamilton, Chair, Membership Committee

\section{NC Paraprofessional Association (NCPLA)}

\section{Update}

- Increased postings on Web site, including updated and revised promotional materials

- Published Visions, the NCLPA newsletter, online only.

- Saves money previously spent on postage, paper, and mailing supplies

- Provides wider audience for support staff information

- Continued using Paraprose, NCLPA blog, to supply timely information and announcements of interest to the library community

- Utilized Google Group discussion forum to facilitate timely communication among Executive Board members

- Issued ballot for election of 2009-2011 officers via Survey Monkey, saving NCLA office time and NCLPA money

- Began exploring ways to conduct online special meetings of the NCLPA Executive Board because of current economic downturn and travel restrictions

- Revised duties in "A Manual for Officers and Committees" (NCLPA Handbook) to include mentoring of incoming officers

\section{NCLA Biennial Conference Activities and Programs}

- Anna Dulin, Library Specialist III, Access Services Department, Z. Smith Reynolds Library, Wake Forest University, WinstonSalem, was the winner of the 2009 Meralyn G. Meadows North Carolina Library Association Paraprofessional Conference Scholarship.
- "Birthday Bash" was the NCLPA theme at the conference:

- Bookmarks highlighting 20 years of NCLPA accomplishments were included in attendees' registration packets;

- Free birthday cake squares were served at the NCLPA display table.

Following is the Conference Programming for the $58^{\text {th }}$ Biennial Conference held in Greenville, NC.

"Cataloging: Who Knew It Was Community Service?"

Presented by Erin Stalberg and Laura Abraham, NCSU Libraries. Group of volunteers from the North Carolina State University Libraries went to the Joel Lane House Museum, the 
oldest house in Raleigh, to "flash-mob" catalog their collection of books using the Web site LibraryThing.

"Mascots Serving Your Library"

Presented by Angela McCauley, Harnett County Public Library; Melanie Holles, Stanly County Public Library; Gloria F. Sutton, Braswell Memorial Library. Mascot Variety Show demonstrated how mascots can be used to market libraries.

"Support Staff Certification: Is It Right for Me?"

Presented by AnnaMarie Kehnast, LSSIRT, ALA. American Library Association (ALA) announced approval of the first national, voluntary certification program for library support staff.

\section{"Game Show Mania"}

Presented by Bill Grimsley, Magic Productions, Inc. Fun-filled and often frenetic TV-style game show engaged and entertained audience during NCLPA luncheon.

\section{"Secrets of the Trade"}

Presented by Bill Grimsley. Magic workshop, a hands-on program to teach the tricks of the trade with a mini-bag of tricks for participants to take home.
"The Sustainable: Lessons from Joyner Library's Green Task Force"

Presented by Joyner Library Staff, East Carolina University, Greenville, NC. Session focused on organization of the Green Task Force, developing a mission and goals, developing obtainable strategies, green projects, tools for communication, lessons learned, and suggestions for the future.

Submitted by Marcia Johnson,

NCLPA Publications Committee Chair

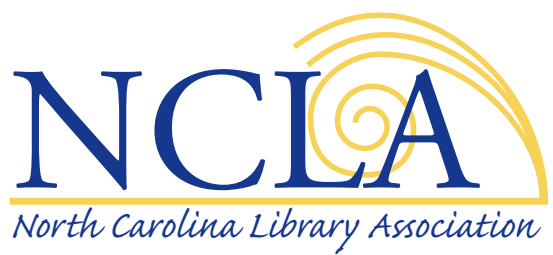

\section{Photos from the 58th Biennial Conference 2009}
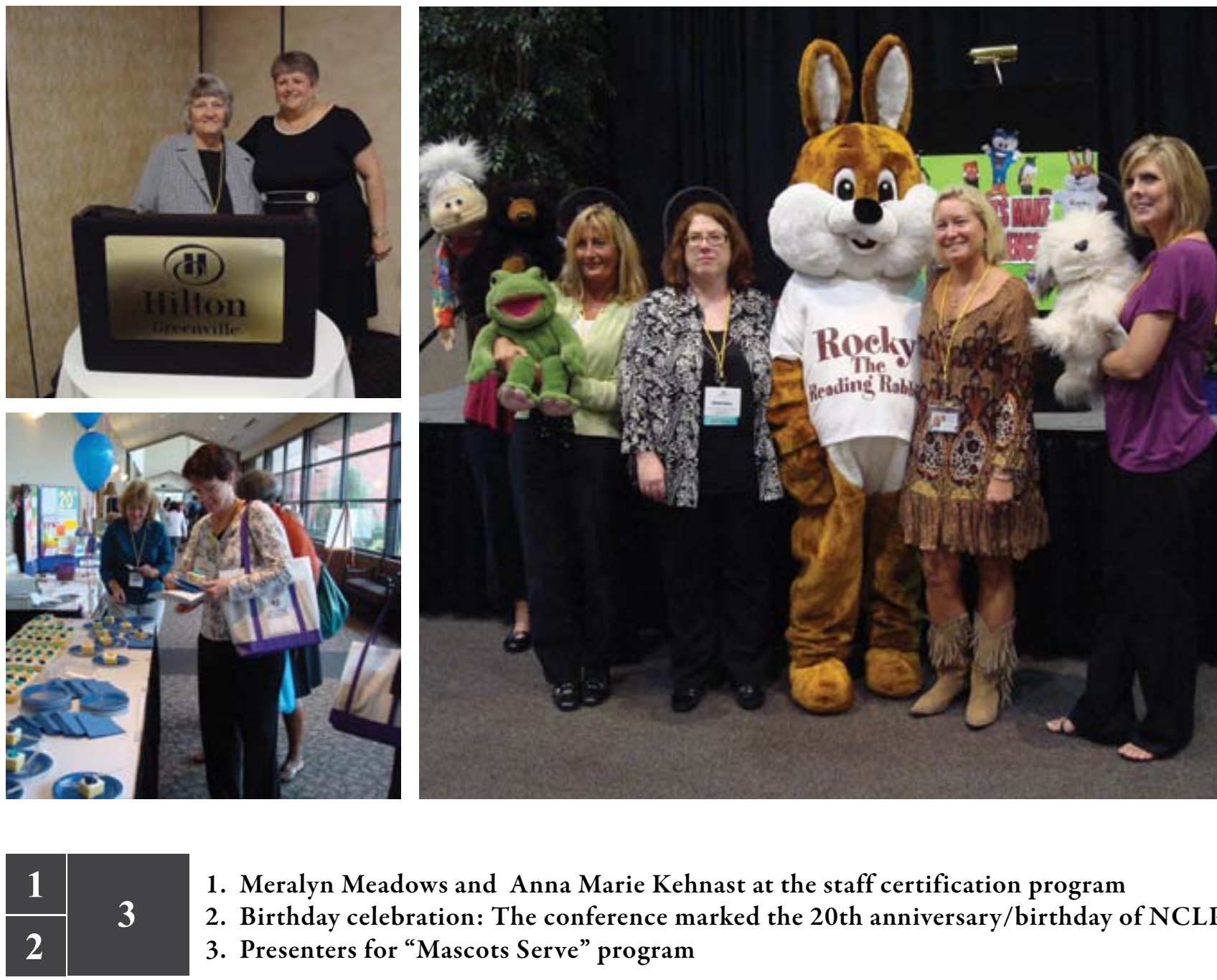

1. Meralyn Meadows and Anna Marie Kehnast at the staff certification program

2. Birthday celebration: The conference marked the 20th anniversary/birthday of NCLPA.

3. Presenters for "Mascots Serve" program 


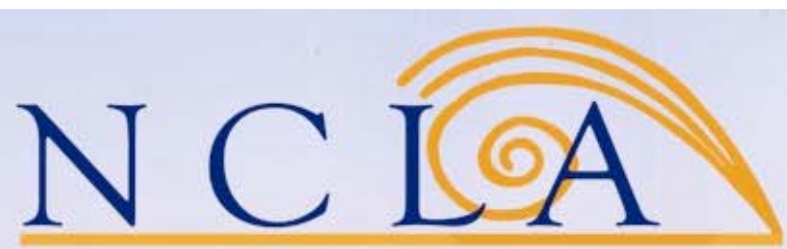

North Carolina Library Association
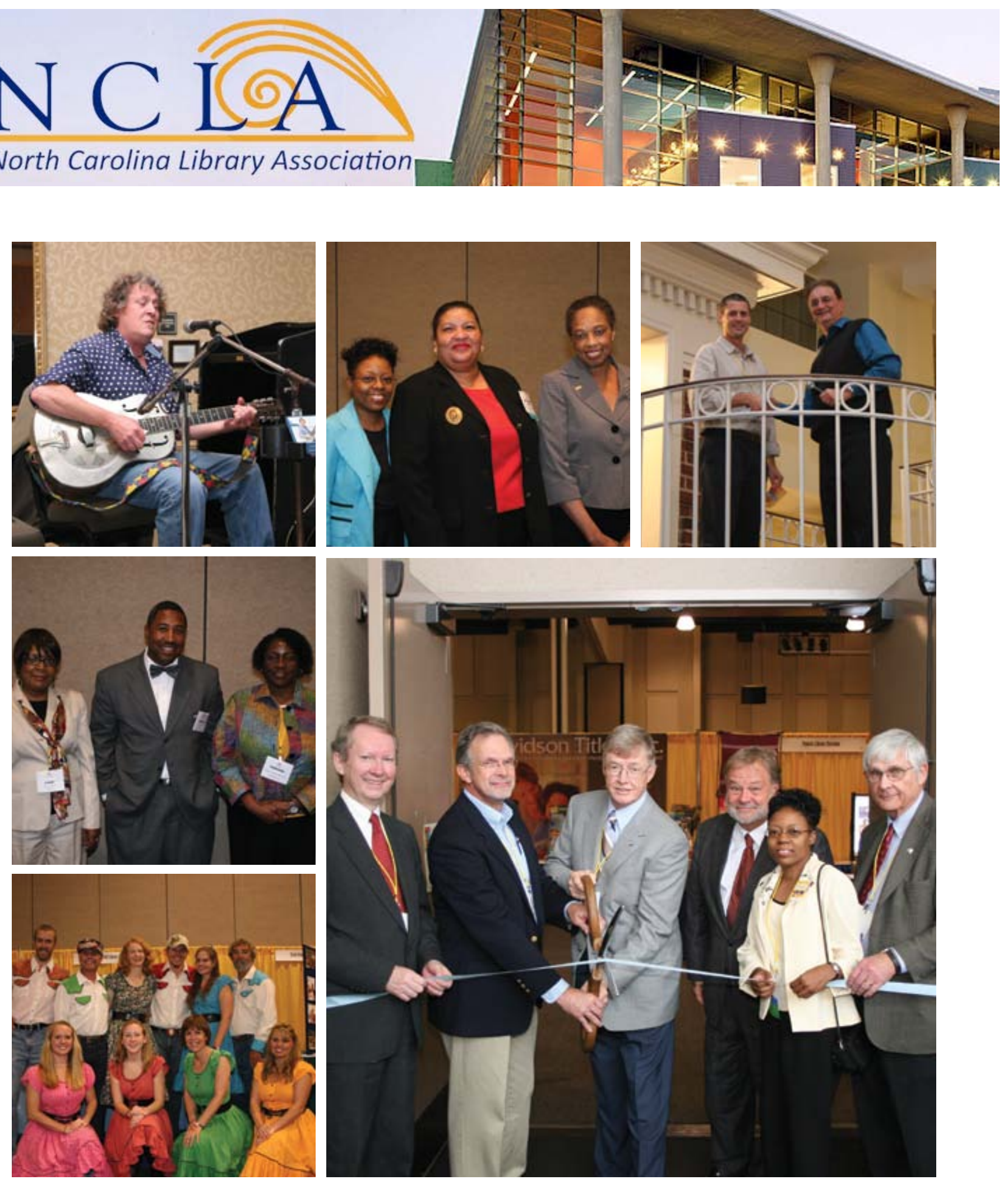

\begin{tabular}{l|l|l|}
\hline 1 & 2 & 3 \\
\hline 4 & \multicolumn{2}{|c|}{6} \\
\cline { 1 - 1 } 5 & \multicolumn{2}{|c}{6} \\
\end{tabular}

1. Mike "Lightnin" Wells

2. (left to right) Sherwin Rice, Barbara White Armstrong, Pauletta Bracy

3. (left to right) Joseph Thomas and Willie Nelms

4. 2009 Roadbuilders' Award Winners (left to right) Jamane Yeager, Jamal L. Cromity, Dr. Claudia Gollop

5. The Green Grass Cloggers

6. President Rice cuts the opening ribbon with past President Robert Burgin 